UDC: $141.319 .8: 316.72(477)$

\author{
M. I. BOICHENKO ${ }^{1 *}$, O. V. YAKOVLEVA ${ }^{2 *}$, V. V. LIAKH ${ }^{3 *}$ \\ 1*Taras Shevchenko National University of Kyiv (Kyiv, Ukraine), e-mail boychenko_m@univ.net.ua, \\ ORCID 0000-0003-1404-180X \\ ${ }^{2 *}$ Kiev Institute of Business and Technology (Kyiv, Ukraine), e-mail rector@kibit.edu.ua, ORCID 0000-0003-4056-2772 \\ ${ }^{3 *}$ H. Skovoroda Institute of Philosophy, National Academy of Sciences of Ukraine (Kyiv, Ukraine), e-mail vvlvv2012@ukr.net, \\ ORCID 0000-0003-4683-0838
}

\title{
CIVILIZATIONAL AND INSTITUTIONAL ASPECTS OF NATIONAL SELF-IDENTIFICATION IN UKRAINE: PHILOSOPHICAL- ANTHROPOLOGICAL APPROACH
}

Purpose. This article clarifies the significance of the person's social self-identification as a basis for civilization and institutional explanation of national self-identification in Ukraine. Theoretical basis. The authors found that the analysis of the cultural and anthropological principles of national self-identity reveals two main opposed concepts: the concept of "eastern" cultural and social self-identity of Ukraine, which correlates with the metaphor of the split between "East" and "West", and the concept of "western" projection of the European future of Ukraine, which correlates with the metaphor of the bridge between "East" and "West". These concepts reflect the options for the citizens of Ukraine to make a personal choice of the way in achieving social self-identity. Douglas North's concept of "openaccess order" states and "limited access order" states can be used as a basis for an alternative, pragmatic approach to choice the criteria of national self-identity. Originality. National self-identification is a result of the choice of the person's self-identification: still the person takes into account the history of the nation, the ethnic diversity of the nation, its cultural and civilizational characteristics. The philosophical-anthropological approach contributes to the demystification of the grounds of social self-identification, revealing the decisive role of the personal choice in shaping the new institutional foundations of national self-identity. Harmonization of the social institutions of Ukraine with the institutions of the European Union and the international community institutions opens wide opportunities for Ukraine's successful integration into the "open-access order" societies. The clarification of the value and symbolic aspects of national self-identity in Ukraine contributes to the successful functioning of these institutions. Multilingualism is an adequate response to the global challenge of the reconstruction of Ukraine's national selfidentity. The education system is a key area for introducing multilingualism. Conclusions. The development, justification and systematization of cultural and institutional criteria for choosing the best ways to strengthen of national self-identity in Ukraine are a prerequisite for the successful self-identification of Ukrainian citizens in a complex and ever-changing global world.

Keywords: human being; personality; person's national self-identification; new institutionalism; civilization; culture; values; multilingualism

\section{Introduction}

Reasoning about the person's national self-identification in Ukraine as an independent country and self-governing society involves the selection of criteria, and therefore the grounds for such self-identification. In modern theoretical thought, as a rule, researchers turn with this purpose to the concept of a political nation as formed on the basis of the personal choice of every citizen. Unlike the ethnic definition of a nation which claims that the person is subordinate to the nation, the concept of political nation appeals primarily to the cultural and, in particular, institutional grounds for social self-actualization of the person. However, social institutions also do not appear to a man as deus ex machina, but are the result of human evolutionary achievements: moreover, if the first social institutions arose mainly spontaneously, then over time the reflexive and socially constructive component of institutional change is steadily increasing. So, when it is declared that a state appears as a main institution of the establishment of a political nation and one of the main instruments for the implementation of the relevant cultural policy, then it does 
not mean spontaneous processes of the emergence and disappearance of the states, it does not mean "national competitions", but it means the realization of specific political projects with their authors and target audience, and these historic actors are the real creators of statehood. Thus, people of some country are belonging to different ethnic groups, they could be the bearers of different languages, traditions, values - but still they could unite into one political nation, provided their agreement on a common future within the framework of a single political nation as a symbol of existence of some common social norms that correspond to specific values of each specific community inside this country. To study such a problem is not task for sociology or cultural studies, because as the basis here should be not positivism, not the statement of the current affairs, but the normative approach, the will to assert those social norms that express to a greater degree not existing, but for granted. To reveal the essence of such an approach and the role of anthropological factor in nation-building it should be involved philosophical vision with specific optic and evaluation of the opportunities and perspectives. Thus, in this article the question of determining the principles of national identity will be interpreted from the point of philosophicalanthropologic analysis of the possible ways in the formation of a political nation facing the challenges of the global age.

The topic of national identity is sufficiently developed at the level of the general theory and at the same time presented by very different and even competitive concepts. Such diversity is conditioned by the different social and historical experience of establishing the national identity among different peoples and countries, as well as the presence of various methodological approaches to constructing relevant concepts. In particular, we are talking about the works of such authors as German philosopher of the late 18th and early 19th century Johan Fichte (2017) (nation as a result of national self-consciousness), British social theorist Anthony Smith (2008) (national identity as based on hierarchy, covenant and republic), modern American social theorist and political scientist Benedict Anderson (2006) (nation as an imagined community) etc. The situation of cultural diversity is inherent in contemporary European societies, most of them are highly differentiated and can be characterized in the terms of multiculturalism. In his analysis of modern cultural communication French postmodernist philosopher Jean Baudrillard in an interview with D. Smith (2017) emphasizes the authenticity of cultural differentiations unlike cultural totalities as meta-narratives.

As a methodology in this article we applied American anthropologist Clifford Geertz's (1973) ideas of symbolic anthropology and his interpretative methodology to the solving of the problem of correlation between civilizational and institutional aspects of national self-identification. The basic approach for such kind of research was proposed by American and Israeli social theorist Shmuel Noa Eisenstadt (1978) in his Revolution and the Transformation of Societies: A Comparative Study of Civilizations. In this study he revealed the selective affinity of symbolic, institutional and structural dimensions of societies. So we demonstrate how some values and symbolic systems help person to identify oneself at some institutional and social-structural position.

All these ideas can be more or less successfully comprehended by the institutional approach presented in the last decade by the writings of such researchers, which we can describe as modern neo-institutionalists: American social theorist, winner of the Nobel Prize for Economics Douglass C. North with co-authors (North, Wallis, \& Weingast, 2013), American social theorists-economists Daron Acemoglu and James A. Robinson (2012), and possibly American political scientist and political technologist Alec Ross (2016). Neo-institutionalism proceeds from the standpoint that social institutions play a decisive role in social change, and these institutions themselves are subject to unceasing modernization in modern society. Neo-institutionalists see 
social institutions in anthropological way - as a result of institutional design, which is carried out by the people themselves. Particular emphasis is being made on the normative side of the functioning of society: social institutions no longer appear to be higher than individual realities, as it was in the case of classical institutionalism, but social institutions are already interpreting as a result of people's legitimization of existing social norms and the creation of new social ones, so institutions operate in the mode of their constant reconstruction and innovation.

This article will attempt to give a new institutional understanding of multiculturalism as the theoretical basis for study of national self-identity.

\section{Purpose}

This article should clarify the significance of the person's social self-identification as the basis for civilization and institutional explanation of national self-identification in Ukraine.

\section{Statement of basic material}

The theme of social self-identity should be distinguished from the topic of personal selfidentity. Thus, British philosopher from University of Sheffield Eric Olson (2015) reveals the connection of personal identity with the biological basis of this identity: "What is necessary, and what suffices for somebody to consider as a person, as opposed to a nonperson? What have people got that non-people haven't got? More specifically, we can ask at what stage in one's development from a fertilized egg there comes to be a person, or what it would take for a chimpanzee or a Martian or an electronic computer to be a person, if they could ever be". When we talk about social identity, we have to look for other criteria, in particular cultural ones. In the global world this becomes a matter of intercultural communication. The formation of a social self-identity itself is critically dependent on solving the issue of multiculturalism. An important example is the solution to this issue in contemporary China, in particular due to the fact that many Chinese students receive education abroad. Modern social education researchers Qiang Liu from Institute of International and Comparative Education, Beijing Normal University and David Turner from the School of Education, Early Years and Social Work, University of South Wales point out important thoughts on this topic:

Generations of students who have studied abroad were closely linked

with the modernization of China, they had promoted China's modern so-

cial transformation and social development in various fields, broadening

and deepening the Sino-Western cultural exchanges, narrowing the gap

between China and the developed countries, showing the strong repair

ability of Chinese culture, and enabling the Chinese civilization to last till

now. With the strengthening of China's comprehensive national position,

China is shaping national identity with a more positive attitude and buil- 
ding consensus for the further development of the Chinese nation through strengthening cultural self-confidence. (Liu, \& Turner, 2018, p. 7)

Ukraine and its education system face a similar problem. Its consideration may become the key to determining the safe way to reconstruct the national self-identity in Ukraine, which has to set a social identity of the individual over his/her personal self-identity.

Already the philosophy of the Enlightenment has created the basis for understanding the social self-identity of the individual as a component of social modernization and modern Western culture. This was analyzed by Ukrainian philosophers V. V. Khmil and O. M. Korkh:

...the idea of self-determination of an individual in the philosophy of

Enlightenment is correlated not only with the recognition of natural human

rights, but with the search for ways to include him/her in the system of cur-

rent law, the conditions for the harmonization of private and public inter-

ests... All these ideas have been expressed in the philosophical and legal system of liberalism, which arose as a result of the synthesis of the concepts of individualism and rationality, and became the ideological basis for the modernization of Western civilization. (Khmil, \& Korkh, 2017, p. 132)

According to Ukrainian philosopher Vitaliy Lyakh:

Modern social development is connected simultaneously both with improvement of human capital and institutions and with orientation on the latest informational and communication technologies. Finally, one can conclude that economic, cultural and political transformations are so related to each other in their development that this relationship allows to predict the nature of their influence on society. (Lyakh, 2016, p. 15)

So in social theory and practice after postmodernist criticism we should talk about social constructivism as dominate position. So we could interpret the position of Ukrainian philosopher T. V. Danylova (2017) as post-postmodern: "The search for the "Self" is largely a reaction to the conviction that science is able to explain the world and determine human's place in it. Basically, this is due to the recognition that the reality we perceive is not the reality per se, but rather it is constructed by the mind" (p. 8). But we focus our research on the source material for this con- 
struction that is still civilizational and institutionally dependent. Anyway, national identity is a topic in which the problems of personal self-identification are close connected with the problems of the social order.

Indeed, already leading representatives of German philosophical anthropology, such as Helmut Plessner and Arnold Gehlen, have been exploring the subject of anthropological foundations of national identity. Arnold Gehlen (1988) considered social institutions as a way of person's unloading to perform new social tasks. In this case, institutes appear to Gehlen not only as a result of the evolution of humanity, but as a result of social creativity of the people themselves. Plessner (2010) wrote that this creativity should become more conscious and master the elemental social processes: he warned against trying to appeal to the supposedly "natural" principles of sociality, and accordingly - from underestimating by the individual his/her own social selfdetermination.

Existing studies of the modern, in some aspects of the postmodern and in some aspects of the modern of a new type, conditions for the formation of a national identity are fragmented rather than systematic as a result of the lack of a coherent vision of the whole spectrum of possible conceptual implementations in the multiculturalism of the national community in the project of creating a national identity. Social values, as Mykhailo Boichenko and Yuriy Miroshnichenko (2016) substantiate, emerge in the common social experience and are fixed in specific stable communicative communities, which become the basis for the creation of more general social formations to provide a valuable basis for the functioning of various social institutions, including the state. Ukrainian philosopher Olena Yakovleva (2015) has worked out specified data on the historical, economic, political and educational circumstances that reveals the origins, main characteristics and prospects for the further development of multilingualism policy in Ukraine.

When it comes to the so-called civilizational discourse, it turns out that it were necessary to prove initially that Ukraine does not "simply" belong to the Slavic civilization, varies from East Slavic civilization, the Orthodox Territories, to the Eurasian world, the Byzantine tradition, and even "Russian world". As a compromise some Ukrainian researchers suggested for Ukraine a painful break with Slavic civilization towards Western Europe civilization -so some of them use the concept of "split civilization" for the civilization status of Ukraine. This controversial concept was elaborated first in Nadia Skotna's (2005, p. 12) work, then it was explicated in publications of the Ukrainian philosopher, sociologist and political scientist Mykola Mykhalchenko and the Ukrainian political scientist and social psychologist Yury Shaygorodskyi (Mykhalchenko, \& Shaihorodskyi, 2006). Is there really an effect of split? Does every Slavic nation necessary belong to the eastern type of civilization? Is Ukraine in a situation of cultural, political or any other "gap" between East and West? Perhaps this situation should be interpreted with a help of another metaphor - for example, the metaphor of the bridge, namely, the bridge between East and West? The first version of the interpretation of the conceptual framework "East-West", namely the version of the "split", seems to us deeply alien to the domestic mentality, and most importantly - to the national interests of Ukraine. On the other hand - the last version of the interpretation, namely the version of the "bridge", helps to understand the same conceptual framework already in a constructive sense for Ukraine. For these interpretations there are both political and scientific reasons, so it should be made rather philosophical choice between them.

These different metaphors and their related interpretations are supported mainly by representatives of different institutions, as well as different countries. The metaphor "split" is propagated by the supporters of the concept of predictable "oriental" cultural and even societal identity of Ukraine. In philosophic field the "oriental" origin and "oriental" nature of Ukrainian society are 
attributed by the adherents of the philosophy of Eurasia, the "Russian world", predominantly Russian philosophers, representatives of the conservative and right political wing - such as Nicolay Trubetskoy (1927) and Alexander Dugin (2015). In the contrast, the metaphor "bridge" is supported by representatives of the "western" projection in the European future of Ukraine - and this is mainly by representatives of Western countries and Western institutions. The metaphor "bridge" is close to Douglass North's concept of "open access orders", correspondently the metaphor "split" is close to his concept of "limited access orders" (North, Wallis, \& Weingast, 2013, p. 148). Philosophy of exclusivity (nation as a cultural and political monad) should be changed by philosophy of inclusivity (nation as a part of multicultural world).

Such a division into the "East" and "West" has its origin from the controversy of "Westerners" and "Slavophiles" at the beginning of the nineteenth century in Tsarist Russia, and the attribution of Ukraine to the "Eastern" civilizational identity was stated in 19th century by Russian philosopher Nicolay Danilevskiy (1995), obviously inspired by these controversies. However, the very definition of "East" and "West", in our opinion, is quite artificial and too conditional. Already in different countries of Europe, the "West" was understood otherwise. Still it is enough to refer to Oswald Spengler (2007), for whom the "western countries" ("das europäischnordamerikanische Abendland") are, first of all, Great Britain, France and USA. Also, traditionally the "East" countries for European thinkers are first of all the countries of Muslim and Confucianism regions. Russia and Ukraine as the "East" have never clearly even been marked in Europe. With the expansion of international politics, economics and other spheres of social life to the global scale, the division into the "West" and "East" in general has lost its meaning: any point at the planet in one respect is "West", and in the other -"East". Thus, the discourse concerning the model of opposition "East-West" is an anachronism in the era of globalization and the growth of the influence of global institutions. If we consider issues not in the terms of abstract models, but in their concrete social relations, then we should accept that globalization does not completely eliminate the differences between countries- cultural, economic, and political (as a matter of fact they will always remain), but in any case globalization largely aligns their significance as parts of a single whole: they lose their uniqueness and identity, since their preservation now depends not only, and not even so much on internal causes (traditional social determination), but depends on the circumstances of the functioning of the global whole, without which these local causes can no longer operate. It could be evidently illustrated by examples from Alec Ross's (2016) The Industries of the Future, chapter 1 (omnipresence of robotization in close future and the problem of employment for every national economic), and Daron Acemoglu's and James Robinson (2012) Why Nations Fail, chapter 12-14 (solution of economic and political problems due to transformation of national institution from their exclusive status to the inclusive one).Philosophical idea of dynamic unity through diversity receives its implementation in the political concept of national institutional design as a local response to a global system challenge. Thus, the most frequent question is about to which extent and how long the old cultural or other social disparities retain their residual influence. Thus, the question cannot be taken in such a way that Ukraine must be completely defined as either part of the "West" or as part of the "East". One can only fight for the domination of European values in Ukraine so that everyone aspires to defend here and now his own dignity and the right to decide what his future will be. Struggling for European values appeared to be attracted by an increasing number of Ukrainian citizens, and vice versa, fewer Ukrainian citizens have preferred the values of "guided democracy", in which the course of the country is clearly outlined by "wise leaders" who have already assumed respon- 
sibility for all citizens, deciding without them and instead of them, how to live and when to die, for what values and in what kind of country.

From these positions it is difficult to agree with the pessimistic overall assessment of the Slovenian political scientist Lucas Žalek (2016) who "concluded that Euromaidan has been a critical turning point in history of modern Ukraine, but path to economic recovery and real association with European structures is a much more complicated process" (p. 150). This author is precisely demonstrates positivist criticism and underestimates the power of mass legitimization of normative changes, the high dynamics of contemporary institutional changes in Ukraine. A more balanced position is demonstrated by other Slovenian political scientists - Martin Solik, Ján Fil'akovský, Vladimír Baar (2017), who claim that despite the rise of the idea of an autocephalous Ukrainian church after Euromaidan in Ukraine, nevertheless, as in Belarus "the role of autocephalous Orthodox churches in building national identities of Belarusians and Ukrainians is also significantly influenced by the political situation in these countries" (p. 155). The political situation of strengthening national identity through autocephaly can only be welcomed. However, religious changes cannot replace the necessary economic reforms, although they could increase the motivation of Ukrainian citizens to them. The economy, however, focuses mainly on the trend of building society "open access order", and religious change can both promote and prevent it. Thus, excessive accentuation of the role of one church in Ukraine can lead to tension in its relations with other religious organizations in Ukraine, as this would be contrary to the principle of "open access".

To receive multiply lingual competence seems to be one of the undoubted cultural priority for the modern person who is looking for success in multicultural society. Thus the policy of multilingualism and establishing of the relevant social and first of all academic institutions is the way to self-identification of inclusive type. Multilingualism in the philosophical, academic and educational aspects in the modern era is the imperative of the progress of modern societies. Multilingualism in theoretical and practical aspects appears as a multifaceted, systemic phenomenon that has wide humanistic value consequences, far exceeds the narrowly pragmatic approach to education as a way of acquiring a profession. As Olena Yakovleva observes, multilingualism in the system of higher education should be considered:

....as a key factor in the context of the philosophical-educational search

for a balance between the value assertion of national consciousness and

identity, on the one hand, and functionally conditioned pragmatism and

communicative expediency, on the other... the multilingualism organi-

cally combines the value and functional tasks of the system of higher

education. (Yakovleva, 2015, p. 39)

Trilingualism (state language, English as a second and additional foreign, including national minority languages) is the best institutional choice for Ukraine today, but in the context of globalization, this format can also change quite quickly. However, the multilingual strategy itself will remain unchanged as one of the key institutional factors for strengthening of Ukraine's national identity. 
Multilingualism is emerging as an example of a successful, modern educational institution that has received not only a positive local historical experience but due to a conscious institutional design - takes also a positive institutional experience from other countries. At the beginning of the establishing of such new institutions, the personal efforts of their co-authors are critical: from the authors of the relevant bills to the participants in the implementation of the laws of Ukraine, adopted on the basis of these bills. In modern Ukraine, the case of introduction of multilingualism in Ukrainian education could show that the anthropological factor affects not only in the sense of biological anthropology, but also as a cultural and anthropological factor, which is increasingly being implemented through the concrete efforts of individuals consciously focused on institutional changes. Such changes lay on the basis of a new national identity of a citizen of Ukraine.

\section{Originality}

Social self-identification could be analyzed as a social process determined by values and intentions as well as historical specific and ethnic diversity. Social structure of Ukraine becomes more transformative and receptive to the institutional design. Many social institutions in Ukraine need to be coordinated with institutions of European Union and international community in the mode of integration of Ukraine to the "open access order" societies. This task could be convincingly fulfilled only due to the clarification of the value and symbolic aspects of social self-identity in Ukraine. Philosophical approach helps to avoid excessive political engagement and disclosures attempts to mystify the grounds of social self-identification. In the global world the religious or every other cultural interpretation of civilization could not be exclusive basis for the social sel-fidentification. But still for Ukrainians European values are significant reason for the choice of European identity. It is the choice of democratic way of life as joint of European values, institutions and standards of living. In modern global society the traditional concepts of the cultural "West" and "East" lost a part of their meaning and should be replaced by the concepts of "open access order" and "limited access order". The concepts of cultural "West" and "East" have still superfluous religious connotations in social sciences and national policy. The concept of "open access order" can be the synthetic basis for the new social and national self-identification in Ukraine. Multilingualism can be one of the practical ways in establishing "open access order" as a basis for the new social self-identification. Multilingualism presents new cultural and institutional strategy itself, which gives successful response for the global challenge to the national identity.

\section{Conclusions}

The challenge for Ukrainian humanities in general and especially for the Ukrainian philosophy is to identify the systemic principles for establishing a national identity of Ukrainian citizens that will promote the development of the ethnic, political, legal, religious, economic, cultural and other aspects of Ukrainian society.This cultural diversity in its plurality, complementarity can contribute to the formation of common orientation of Ukrainian citizen to strengthen the Ukrainian state among other European states - as a way to successful integration into the world community. Such a response is possible, first of all, on the basis of the development of the civil society in Ukraine, as well as a result of the development of a systemically grounded concept for identifying ways of strengthening the national identity of Ukrainian citizens in the values of multiculturalism. This concept should also be provided for a significant ideological and methodological effect, with the involvement of its ideas and propositions in the state programs, their dissemination in the scientific, public-political and media spheres through the publication of the re- 
sults of relevant scientific researches, due to the participation of its supporters in scientific conferences and other public events, as well as due to the involvement of its followers in academic sphere (students, $\mathrm{PhD}$ program students, professors etc.). Thus, such a response has interconnected scientific, socio-political and cultural-anthropological significance. Reconstruction of Ukraine's national self-identity is an institutional task that at the theoretical level requires further philosophical-anthropological reflection on the civilizational and cultural aspects of the functioning of social institutions in Ukraine.

\section{REFERENCES}

Acemoglu, D., \& Robinson, J. (2012). Why nations fail: The origins of power, prosperity, and poverty. New York: Crown. (in English)

Anderson, B. (2006). Imagined communities: Reflections on the origin and spread of nationalism. London: Verso Books. (in English)

Boichenko, M., \& Myroshnichenko, D. (2016). Intellectuals and students: The development of their relations from theory to practice. Revista de Filosofie, Sociologie și Științe Politice, 2(171), 152-160. (in Russian)

Danilevskiy, N. Y. (1995). Rossiya i Yevropa: Vzglyad na kulturnye i politicheskie otnosheniya Slavyanskogo mira $k$ Germano-Romanskomu (6 Edit.). St. Petersburg: Glagol: St. Petersburg University. (in Russian)

Danylova, T. V. (2017). Searching for the true self: The way of nondual wisdom. Anthropological Measurements of Philosophical Research, 12, 7-15. doi: 10.15802/ampr.v0i12.119069 (in English)

Dugin, A. (2015). Eurasian mission: An introduction to Neo-Eurasianism. Budapest: Arktos Media Limited. (in English)

Eisenstadt, S. N. (1978). Revolution and the transformation of societies: A comparative study of civilizations. New York: Free Press. (in English)

Fichte, J. G. (2017). Die reden an die deutsche Nation. Berlin: Holzinger. (in German)

Geertz, C. (1973). The interpretation of cultures: Selected essays. New York: Basic Books. (in English)

Gehlen, A., \& K. Rehberg (Ed.). (1985). Philosophische anthropologie und handlungslehre (Vol. VI). Frankfurt am Main: Klostermann Vittorio Gmbh. (in German)

Khmil, V., \& Korkh, O. (2017). The concept of self-determination in the philosophy of the Enlightenment. Anthropological Measurements of Philosophical Research, 11, 127-134. doi: 10.15802/ampr.v0i11.105496 (in Ukrainian)

Lyakh, V. V. (2016). Values Patterns shift in the context of transition from modern to postmodern situations. Multyversum. Filosofskyi Almanakh: Collection of scientific papers, 5-6, 3-17. (in Ukrainian)

Liu, Q., \& Turner, D. (2018). Identity and national identity. Educational Philosophy and Theory, 50(12), 1080-1088. doi: 10.1080/00131857.2018.1434076 (in English)

Mykhalchenko, M., \& Shaihorodskyi, Y. (2006). Tsyvilizatsiina chy tsinnisna rozkolotist Ukrainy? Political Management, 6, 18-28. (in Ukrainian)

North, D. C., Wallis, J. J., \& Weingast, B. R. (2009). Violence and social orders: A conceptual framework for interpreting recorded human history. Cambridge: Cambridge University Press. (in English)

Olson, E. T. (2015). Personal identity. Stanford Encyclopedia of Philosophy. Retrived from https://plato.stanford.edu/entries/identity-personal/ (in English)

Plessner, H. (2010). Grenzen der Gemeinschaft. Eine Kritik des sozialen Radikalismus. Frankfurt am Main: Suhrkamp. (in German)

Ross, A. (2016). The industries of the future. New York: Simon \& Schuster. (in English)

Skotna, N. (2005). Osoba v rozkolotii tsyvilizatsii: Osvita, svitohliad, dii: Monohrafiia. Lviv: Ukrainski tekhnolohii. (in Ukrainian)

Smith, A. D. (2008). The cultural foundations of nations: Hierarchy, covenant, and republic. Hoboken: John Wiley \& Sons. (in English)

Smith, R. G., \& Clarke, D. B. (Eds). (2017). Jean Baudrillard: The disappearance of culture. Uncollected interviews. C. Turner, Trans. Edinburgh: Edinburgh University Press. (in English)

Solik, M., Filakovský, J., \& Baar, V. (2017). Belarusian and Ukrainian autocephalous orthodox churches and national identity: Comparison. Political Sciences, 20(2), 116-163. (in English)

Spengler, O. (2007). Der Untergang des Abendlan des. Düsseldorf: Patmos Verlag. (in German) 
Trubetskoy, N. (1927). K ukrainskoy probleme. In Yevraziyskiy sovremennik (Book V, pp. 165-184). Paris. (in Russian)

Yakovleva, O. V. (2015). Multilingualism of Ukrainian society as a regulatory factor in the education and upbringing system of higher education in the context of world experience. (Avtoreferat dysertatsii doktora filosofskykh nauk). National Academy of Educational Sciences of Ukraine, Kyiv. Retrived from http://www.ihed.org.ua/images/doc/ogoloshenya_pro_zahisti/Yakovleva_27.01.2015_avtoref.pdf (in Ukrainian)

Žalek, L. (2016). The Ukrainian crisis - A new start of self-aware nationhood or gradual decline of the state? Political Sciences, 19(4), 137-155. (in English)

\section{LIST OF REFERENCE LINKS}

Acemoglu, D. Why nations fail: The origins of power, prosperity, and poverty / D. Acemoglu, J. Robinson. - New York: Crown, 2012. -529 p.

Anderson, B. Imagined Communities: Reflections on the Origin and Spread of Nationalism / B. Anderson. London: Verso Books, 2006.- 240 p.

Бойченко, М. Интеллектуалы и студенты: развитие отношений от теории к практике / М. Бойченко, Д. Мирошниченко // Revista de Filosofie, Sociologie și Științe Politice. - 2016. - № 2 (171). - S. 152-160.

Данилевский, Н. Я. Россия и Европа: Взгляд на культурные и политические отношения Славянского мира к Германо-Романскому / Н. Я. Данилевский. - 6-е изд. - Санкт-Петербург : Глаголь : СанктПетербургский университет, 1995. - 552 с.

Danylova, T. V. Searching for the True Self: The Way of Nondual Wisdom / T. V. Danylova // Антропологічні виміри філософських досліджень. - 2017. - Вип. 12. - С. 7-15. doi: 10.15802/ampr.v0i12.119069

Dugin, A. Eurasian Mission: An Introduction to Neo-Eurasianism / A. Dugin. - Budapest : Arktos Media Limited, 2015. -182 p.

Eisenstadt, S. N. Revolution and the Transformation of Societies: A Comparative Study of Civilizations / S. N. Eisenstadt. - New York : Free Press, 1978. - 348 p.

Fichte, J. G. Die Reden an die deutsche Nation / J. G. Fichte. - Berlin : Holzinger, 2017. - 254 s.

Geertz, C. The Interpretation of Cultures: Selected Essays / C. Geertz. - New York : Basic Books, 1973. - 470 p.

Gehlen, A. Philosophische Anthropologie und Handlungslehre / A. Gehlen ; hrsg. von K. Rehberg. - Frankfurt am Main : Klostermann Vittorio Gmbh, 1985. - Bd. VI. - 538 s.

Хміль, В. В. Ідея особистого самовизначення в філософії Просвітництва / В. В. Хміль, О. М. Корх // Антропологічні виміри філософських досліджень - 2017. - Вип. 11. - С. 127-134. doi: 10.15802/ampr.v0i11.105496

Лях, В. В. Зміна патернів цінностей в контексті переходу від модерну до постмодерну / В. В. Лях // Мультиверсум. Філософський альманах : зб. наук. пр. / Ін-т філософії ім. Г. С. Сковороди НАН України. Київ, 2016. - Вип. 5-6. - С. 3-17.

Liu, Q. Identity and National Identity / Q. Liu, D. Turner // Educational Philosophy and Theory. - 2018. - Vol. 50, No. 12. - P. 1080-1088. - doi: 10.1080/00131857.2018.1434076

Михальченко, М. Цивілізаційна чи ціннісна розколотість України? / М. Михальченко, Ю. Шайгородський // Політичний менеджмент. - 2006. - № 6. - С. 18-28.

North, D. C. Violence and Social Orders: A Conceptual Framework for Interpreting Recorded Human History / D. C. North, J. J. Wallis, B. R. Weingast. - Cambridge : Cambridge University Press, 2009. - 308 p.

Olson, E. T. Personal Identity [Virtual Resource] / Eric Olson // Stanford Encyclopedia of Philosophy. - 2015. 9 July. - Access Mode: https://plato.stanford.edu/entries/identity-personal/ - Title from the screen. - Date of Access: 19.06.2018.

Plessner, H. Grenzen der Gemeinschaft. Eine Kritik des sozialen Radikalismus / H. Plessner. - Frankfurt am Main : Suhrkamp, 2010. - $145 \mathrm{~s}$.

Ross, A. The Industries of the Future / A. Ross. - New York: Simon \& Schuster, 2016. - 320 p.

Скотна, Н. В. Особа в розколотій цивілізації: освіта, світогляд, дії : монографія / Н. В. Скотна. - Львів : Українські технології, 2005. - $384 \mathrm{c}$.

Smith, A. D. The Cultural Foundations of Nations: Hierarchy, Covenant, and Republic / A. D. Smith. - Hoboken : John Wiley \& Sons, 2008. - 264 p.

Jean Baudrillard: The Disappearance of Culture. Uncollected Interviews / Eds. by R. G. Smith, D. B. Clarke ; Trans. by C. Turner. - Edinburgh : Edinburgh University Press, 2017. - 272 p. 
Solik, M. Belarusian and Ukrainian Autocephalous Orthodox Churches and National Identity: Comparison / M. Solik, J. Fil'akovský, V. Baar // Politické Vedy. - 2017. - Roč. 20, Č. 2. - S. 116-163.

Spengler, O. Der Untergang des Abendlan des / O. Spengler. - Düsseldorf : Patmos Verlag, 2007. - 1249 s.

Трубецкой, Н. К украинской проблеме / Н. Трубецкой // Евразийский современник : [сборник]. - Париж, 1927. - Кн. V. - C. 165-184.

Яковлева, О. В. Багатомовність українського суспільства як регулятивний фактор освіти і виховання в системі вищих навчальних закладів у контексті світового досвіду : автореф. дис. ... д-ра філос. наук : 09.00.10 / Яковлева Олена Вячеславівна ; Нац. акад. пед. наук України, ін-т вищ. освіти. - Київ, 2015. - 40 с. - Режим доступу: http://www.ihed.org.ua/images/doc/ogoloshenya_pro_zahisti/Yakovleva_ 27.01.2015_avtoref.pdf

Žalek, L. The Ukrainian Crisis - A New Start of Self-Aware Nationhood or Gradual Decline of the State? / L. Žalek // Politické Vedy. - 2016. - Roč. 19, Č. 4. - S. 137-155.

\section{М. І. БОЙЧЕНКО ${ }^{*}$, О. В. ЯКОВЛЕВА ${ }^{2 *}$, В. В. ЛЯХ ${ }^{3 *}$}

1*Київський національний університет імені Тараса Шевченка (Київ, Україна), ел. пошта boychenko_m@univ.net.ua, ORCID 0000-0003-1404-180X

2*Київський інститут бізнесу і технологій (Київ, Україна), ел. пошта rector@kibit.edu.ua, ORCID 0000-0003-4056-2772

${ }^{3 *}$ Інститут філософії імені Г. С. Сковороди, Національна академія наук України (Київ, Україна), ел. пошта

vvlvv2012@ukr.net, ORCID 0000-0003-4683-0838

\section{ЦИВІЛІЗАЦІЙНІ ТА ІНСТИТУЦІЙНІ АСПЕКТИ НАЦІОНАЛЬНОЇ САМОІДЕНТИФІКАЦІЇ В УКРАЇНІ: ФІЛОСОФСЬКО- АНТРОПОЛОГІЧНИЙ ПІДХІД}

Мета. Ця стаття прояснює значущість соціальної самоідентифікації особистості як основи для цивілізаційного та інституційного пояснення національної самоідентифікації в Україні. Теоретичний базис. Автори виявили, що при аналізі культурно-антропологічних засад національної самоідентичності одна одній протистоять дві основні концепції: концепція "східної" культурної та суспільної самоідентичності України, з якою корелюється метафора розколу між "Сходом" та "Заходом", та концепція "західної" проекції європейського майбутнього України, яка корелюється з метафорою мосту між "Сходом" та "Заходом". Ці концепції відображають опції особистого вибору шляху здобуття соціальної самоідентичності громадянами України. Концепція Дугласа Норта щодо держав "порядку відкритого доступу" та держав "порядку обмеженого доступу" може бути використана як основа для альтернативного, прагматичного підходу для вибору критеріїв національної самоідентичності. Наукова новизна. Національна самоідентифікація є результатом вибору особистістю своєї соціальної самоідентифікації: при цьому особистість враховує історію нації, етнічне розмаїття нації, ії культурні та цивілізаційні характеристики. Філософсько-антропологічний підхід сприяє демістифікації підстав соціальної самоідентифікації, виявляючи вирішальну роль особистого вибору у формуванні нових інституційних засад національної самоідентичності. Узгодження соціальних інститутів України з інституціями Європейського Союзу та міжнародного співтовариства відкриває широкі можливості успішної інтеграції України до суспільств "порядку відкритого доступу". З’ясування ціннісних та символічних аспектів національної самоідентичності в Україні сприяє успішному функціонуванню цих інституцій. Багатомовність $\epsilon$ адекватною відповіддю на глобальний виклик реконструкції національної самоідентичності України. Система освіти $є$ ключовою сферою запровадження багатомовності. Висновки. Розвиток, обгрунтування та систематизація культурних та інституційних критеріїв вибору найкращих шляхів зміцнення національної ідентичності в Україні є основною передумовою успішної самоідентифікації українських громадян у складному та постійно мінливому глобальному світі.

Ключові слова: людина; особистість; національна самоідентифікація особистості; неоінституціоналізм; цивілізація; культура; цінності; багатомовність 


\author{
М. И. БОЙЧЕНКО ${ }^{*}$, Е. В. ЯКОВЛЕВА ${ }^{2 *}$, В. В. ЛЯХ ${ }^{3 *}$ \\ 1*Киевский национальный университет имени Тараса Шевченко (Киев, Украина), эл. почта boychenko_m@univ.net.ua, \\ ORCID 0000-0003-1404-180X \\ ${ }^{2 *}$ Киевский институт бизнеса и технологий (Киев, Украина), эл. почта rector@ kibit.edu.ua, ORCID 0000-0003-4056-2772 \\ ${ }^{3 *}$ Институт философии имени Г. С. Сковороды, Национальная академия наук Украины (Киев, Украина), эл. почта \\ vvlvv2012@ukr.net, ORCID 0000-0003-4683-0838
}

\title{
ЦИВИЛИЗАЦИОННЫЕ И ИНСТИТУЦИОНАЛЬНЫЕ АСПЕКТЫ НАЦИОНАЛЬНОЙ САМОИДЕНТИФИКАЦИИ В УКРАИНЕ: ФИЛОСОФСКО-АНТРОПОЛОГИЧЕСКИЙ ПОДХОД
}

Цель. Эта статья проясняет значимость социальной самоидентификации личности как основы для цивилизационного и институционального объяснения национальной самоидентификации в Украине. Теоретический базис. Авторы выявили, что при анализе культурно-антропологических основ национальной самоидентичности друг другу противостоят две основные концепции: концепция "восточной" культурной и общественной самоидентичности Украины, с которой коррелирует метафора раскола между "Востоком" и "Западом", и концепция "западной" проекции европейского будущего Украины, которая коррелируется с метафорой моста между "Востоком" и "Западом". Эти концепции отражают опции личного выбора пути получения социальной самоидентичности гражданами Украины. Концепция Дугласа Норта о государствах "порядка открытого доступа" и государствах "порядка ограниченного доступа" может быть использована как основа для альтернативного, прагматического подхода для выбора критериев национальной самоидентичности. Научная новизна. Национальная самоидентификация является результатом выбора личностью своей социальной самоидентификации: при этом личность учитывает историю нации, этническое разнообразие нации, ее культурные и цивилизационные характеристики. Философскоантропологический подход способствует демистификации оснований социальной самоидентификации, выявляя решающую роль личного выбора в формировании новых институциональных основ национальной самоидентичности. Согласование социальных институтов Украины с институтами Европейского Союза и международного сообщества открывает широкие возможности успешной интеграции Украины в общества "порядка открытого доступа". Выяснение ценностных и символических аспектов национальной самоидентичности в Украине способствует успешному функционированию этих институтов. Многоязычие является адекватным ответом на глобальный вызов реконструкции национальной самоидентичности Украины. Система образования является ключевой сферой внедрения многоязычия. Выводы. Развитие, обоснование и систематизация культурных и институциональных критериев выбора лучших путей укрепления национальной идентичности в Украине является основной предпосылкой успешной самоидентификации украинских граждан в сложном и постоянно меняющемся глобальном мире.

Ключевые слова: человек; личность; национальная самоидентификация личности; неоинституционализм; цивилизация; культура; ценности; многоязычие

Received: 27.06 .2018

Accepted: 22.11.2018 